\title{
Effect of camptothecin on inducible nitric oxide synthase expression in the colon cancer $\mathrm{SW480}$ cell line
}

\author{
XIANGDI SHEN $^{1}$, JIAN CHEN $^{1}$, RONG $^{1}{ }^{1}$, XINGLI FAN $^{1}$ and YING XIN ${ }^{2}$ \\ ${ }^{1}$ Department of Basic Science, Zhejiang Medical College, Hangzhou, Zhejiang 310053; \\ ${ }^{2}$ Department of General Surgery, Zhejiang Provincial People's Hospital, Hangzhou, Zhejiang 310014, P.R. China
}

Received October 29, 2014; Accepted August 5, 2015

DOI: $10.3892 / \mathrm{ol} .2015 .3658$

\begin{abstract}
As a topoisomerase I inhibitor, camptothecin (CPT) is regarded as an effective antitumor agent. In an attempt to search for its novel anticancer mechanism, the present study evaluated the effects of CPT on inducible nitric oxide synthase (iNOS) in the human colon cancer SW480 cell line when stimulated with lipopolysaccharide (LPS) and interleukin (IL)-1 $\beta$. The data indicated that CPT significantly decreased NO production. Consistent with these observations, the protein and mRNA expression levels of iNOS were inhibited by CPT in a dose-dependent manner. Thus, the inhibitory effects of CPT on LPS/IL-1 $\beta$-stimulated NO production were likely mediated via the inhibition of iNOS gene transcription. From these results, we propose that the inhibition of NO biosynthesis by CPT may partially underlie the efficacy of this antitumor agent.
\end{abstract}

\section{Introduction}

Camptothecin (CPT) is a pentacyclic alkaloid first isolated from a Chinese tree, Camptotheca acumincta, in the early 1960s (1). CPT is an antitumor agent that is clinically effective, with a broad range of antitumor activities against solid tumors, including breast, ovarian, lung and colorectal tumors (2). The efficacy of CPT is associated with its ability to inhibit the function of DNA topoisomerase I, which is vital for the transcription of supercoiled DNA (3). However, innovations in treatment strategies have been developed, with targets such as oncogenes and elements of cell signaling pathways (4). Tumors are dependent on a switch to an angiogenic phenotype and the resultant formation of new vasculature, and this finding has become the basis of another potential target $(5,6)$. Thus, the inhibition of the blood supply to the tumor is now considered to represent a unique approach for the cessation of tumor growth (7). Certain studies have illustrated that CPT

Correspondence to: Miss. Ying Xin, Department of General Surgery, Zhejiang Provincial People's Hospital, 481 Binwen Road, Hangzhou, Zhejiang 310014, P.R. China

E-mail: shenxiangdi@163.com

Key words: camptothecin, inducible nitric oxide synthase, SW480 also produces an inhibitory effect on the development of the vasculature (8). A previous study has also revealed that CPT can induce the apoptosis of cancer cells (9).

A number of studies have indicated that nitric oxide (NO) synthesized by the NO synthase (NOS) enzyme family is significant in tumor growth, invasion and metastasis $(10,11)$. Mammalian systems contain three well-characterized isoforms of the enzyme: Neuronal NOS (nNOS/NOS-1), endothelial NOS (eNOS/NOS-3) and inducible NOS (iNOS/NOS-2). The activity of iNOS has been found to be inducible in response to stimuli such as proinflammatory cytokines or endotoxin (12). In a number of solid tumors, such as colon and breast carcinoma, the overexpression of inducible NOS has been recently documented $(13,14)$. It has also been suggested that the iNOS activity in tumor tissue is associated with the tumor grade and cell differentiation (15-17). A previous study has indicated that CPT affects the expression of iNOS protein and its activity in the virus-transformed mouse macrophage-like RAW264.7 cell line when stimulated with lipopolysaccharide (LPS) plus interferon- $\gamma(18)$.

The present study investigated whether CPT alters iNOS protein expression in the human colon adenocarcinoma SW480 cell line in order to obtain further insight into the biological effects of CPT on iNOS.

\section{Materials and methods}

Chemicals. CPT was purchased from Sigma Aldrich (St. Louis, MO, USA) and dissolved in dimethyl sulfoxide (DMSO; Sigma Aldrich) at $2 \mathrm{mg} / \mathrm{ml}$, prior to being aliquoted and stored at $-20^{\circ} \mathrm{C}$. Further dilutions were made in phosphate-buffered saline (PBS; Cellgro, Herndon, VA, USA) to the appropriate concentration just prior to use. The final concentration of DMSO in culture did not exceed $0.1 \%(\mathrm{v} / \mathrm{v})$, which is non-toxic to cells. LPS was purchased from Fluka Chemical Corporation (Buchs SG, Switzerland) and interleukin (IL)-1 $\beta$ was purchased from Cytolab Ltd. (Rehovot, Isael). Dulbecco's modified Eagle's medium (DMEM) was purchased from Gibco Life Technologies (Carlsbad, CA, USA). All other chemicals were dissolved in distilled water.

Cell culture. SW480 cells were gained from the Basic Science department at Zhejiang Medical College (Hangzhou, China) and were cultured in DMEM containing 10\% fetal calf serum 
(Sijiqing Company, Zhejiang, China) in a humidified incubator at $37^{\circ} \mathrm{C}$ in an atmosphere containing $5 \% \mathrm{CO}_{2}$. The cells were used between passages 9 and 20 .

Measurement of nitrite. Nitrite production, an indicator of NO synthesis, was measured in the supernatant as described previously (19). The SW480 cells were plated into 96-well tissue culture plates at $2 \times 10^{4}$ cells/well and grown under standard culture conditions. After $12 \mathrm{~h}$, in order to induce iNOS, old culture medium was replaced by fresh culture medium containing LPS $(10 \mathrm{mg} / \mathrm{l})$ plus IL-1 $\beta(20 \mathrm{ng} / \mathrm{ml})$. To assay the effect of CPT on nitrite production, CPT $(0,0.032,0.125,0.5$, $1.0,2.0 \mu \mathrm{g} / \mathrm{ml}$ ) was added in the presence of LPS/IL-1 $\beta$ for $12 \mathrm{~h}$. Nitrite was measured based on the Griess reaction. Cell culture medium $(100 \mu \mathrm{l})$ was mixed with $100 \mu \mathrm{l}$ Griess reagent ( $1 \%$ sulfanilamide and $0.1 \%$ naphthylenediamine in $5 \%$ phosphoric acid) and incubated at room temperature for $10 \mathrm{~min}$. The optical density at $490 \mathrm{~nm}\left(\mathrm{OD}_{490}\right)$ was measured with a microplate reader (SmartSpec ${ }^{\mathrm{TM}} 3000$; Bio-Rad Laboratories Inc., Hercules, CA, USA). A standard curve was prepared for calculating the concentration using the $\mathrm{OD}_{490}$.

Cell viability. Cell viability was determined by MTT assay. A total of $100 \mu \mathrm{l}$ culture medium was present per well following the Griess reaction. MTT was purchased from Sigma Aldrich and was dissolved with PBS. MTT solution $(5 \mathrm{mg} / \mathrm{ml})$ was added in every well. The cells were incubated for $4 \mathrm{~h}$. The supernatant was discarded and then $150 \mu 1 \mathrm{DMSO}$ was added. Agitation was performed for $10 \mathrm{~min}$ and the $\mathrm{OD}_{490}$ was measured. The viability percentage was calculated.

Reverse transcription-polymerase chain reaction (RT-PCR). The SW480 cells were cultured in 100-ml culture bottles. After $12 \mathrm{~h}$, fresh medium with LPS/IL-1 $\beta$ was added to replace the old medium. Next, two concentrations of CPT $(0.032$ and $0.125 \mu \mathrm{g} / \mathrm{ml}$ ) were added after $12 \mathrm{~h}$, and $24 \mathrm{~h}$ later, total cellular RNA was extracted from control and treated cells using TRIzol reagent (Bio Basic Inc., Markham, ON, Canada). Total RNA preparation $(2 \mu \mathrm{g})$ was mixed with oligo(dT) (Invitrogen Life Technologies, Carlsbad, California, USA) for reverse transcription using MMLV to derive the first-strand cDNA. A pair of gene-specific PCR primers (Invitrogen Life Technologies) were designed for iNOS and GAPDH as follows: iNOS, 5'-GATCAATAACCTGAACG-3' and 5'-GCCCTTTTTTGCTCCATAGC-3'; and GAPDH, 5'-ACCACAGTCCATGCCATCAC-3' and 5'-TCCACCACC ATGTTGCTGTAA-3'. PCR was performed with an S1000 ${ }^{\mathrm{TM}}$ Thermal Cycler (Bio-Rad Laboratories Inc.) at $94^{\circ} \mathrm{C}$ for $3 \mathrm{~min}$ for denaturing, followed by multiple cycles at $94^{\circ} \mathrm{C}$ for $45 \mathrm{sec}$, $50^{\circ} \mathrm{C}$ for $1 \mathrm{~min}$ and $72^{\circ} \mathrm{C}$ for $1 \mathrm{~min}$. For iNOS, 36 cycles were performed and for GAPDH, 35 cycles were performed. The PCR products were separated by electrophoresis and their quantity was determined by Quantity One software (Bio-Rad Laboratories Inc.).

Western blot analysis. The SW480 cells were cultured in 100-ml culture bottles. After $12 \mathrm{~h}$, fresh medium with LPS/IL-1 $\beta$ was added to replace the old medium. Next, two concentrations of CPT $(0.032$ and $0.125 \mu \mathrm{g} / \mathrm{ml})$ were added after $12 \mathrm{~h}$, and $24 \mathrm{~h}$ later, the cells were solubilized with lysis buffer. A BCA
Table I. Nitrite production and cell viability of SW480 cell in the presence of CPT for $18 \mathrm{~h}$.

\begin{tabular}{lcc}
\hline $\begin{array}{c}\text { Concentration } \\
\text { of CPT, } \mu \mathrm{g} / \mathrm{ml}\end{array}$ & $\begin{array}{c}\text { Nitrite production, } \\
\mu \mathrm{g} / \mathrm{ml}\end{array}$ & $\begin{array}{c}\text { Cell viability } \\
\text { after } 18 \mathrm{~h}, \%\end{array}$ \\
\hline 0.000 & $26.68 \pm 1.15$ & $99.98 \pm 2.09$ \\
0.032 & $24.71 \pm 1.71$ & $93.93 \pm 6.39$ \\
0.125 & $24.16 \pm 1.37$ & $94.56 \pm 4.91$ \\
0.500 & $23.88 \pm 1.40$ & $93.21 \pm 8.78$ \\
1.000 & $23.68 \pm 0.87$ & $91.04 \pm 4.85$ \\
2.000 & $21.63 \pm 4.59^{\mathrm{a}}$ & $92.58 \pm 4.69$ \\
\hline
\end{tabular}

Effect of different concentrations of camptothecin (CPT) on lipopolysaccharide/interleukin-1 $\beta$-induced nitrite accumulation and cell viability in SW480 cells. The cells were exposed to CPT for $18 \mathrm{~h}$. Results are expressed as the mean \pm standard deviation of 3 observations. ${ }^{\mathrm{a}} \mathrm{P}<0.05$ vs. control $(0 \mu \mathrm{g} / \mathrm{ml})$.

Protein Assay Kit (Amersham, Uppsala, Sweden) was applied to detect the concentration of protein. Lysates containing $5 \mu \mathrm{g}$ protein were separated by SDS-PAGE on $7.5 \%$ polyacrylamide gels with perpendicurity electrophoretic apparatus (EPS 2A200; Amersham) and transferred onto nitrocellulose membranes with a transmembrane machine (semi-dry transfer unit; Amersham). Subsequent to blocking, the membrane was incubated with rabbit polyclonal anti-iNOS body $(1: 2,000$; Santa Cruz Inc., Dallas, TX, USA) for $2 \mathrm{~h}$ at room temperature. Blots were washed with Tris-buffered saline plus Tween-20 and incubated with horseradish peroxidase-conjugated goat anti-rabbit immunoglobulin G (1:5,000; Santa Cruz Inc.) for $2 \mathrm{~h}$ at room temperature. Next, immunoreactive bands were detected with an enhanced chemiluminescence mixture (Sigma Aldrich). Thereafter, the same membrane was stripped and reprobed with rabbit anti- $\beta$-actin (1:2,000; Santa Cruz Inc.). The membrane was placed into a magazine with a film. Following exposure, the film was immersed in development agent for 1-2 min, then in fixer. The film was scanned and the OD value was calculated by Quantity One software.

Statistical evaluation. The results are expressed as the mean \pm standard deviation. Statistical comparisons were made between groups using a one-way analysis of variance. $\mathrm{P}<0.05$ was considered to indicate a statistically significant difference.

\section{Results}

Effect of CPT on nitrite production in SW480. As illustrated in Tables I and II, when the cells were stimulated with LPS/IL-1 $\beta$, the ability of CPT to cause changes in nitrite production was dependent on the concentration of CPT and the duration of incubation with CPT. As shown in Table I, when the cells were incubated in the presence of CPT for $18 \mathrm{~h}$, nitrite production was significantly reduced only at concentration of $2 \mu \mathrm{g} / \mathrm{ml}$. As shown in Table I, all concentrations of CPT did not affect the cell viability of the SW480 cells, even at $2 \mu \mathrm{g} / \mathrm{ml}$. This result indicates that the inhibi- 
Table II. Nitrite production and cell viability of SW480 cells in the presence of CPT for $24 \mathrm{~h}$.

\begin{tabular}{lcr}
\hline $\begin{array}{l}\text { Concentration of } \\
\text { CPT, } \mu \mathrm{g} / \mathrm{ml}\end{array}$ & $\begin{array}{c}\text { Nitrite production, } \\
\mu \mathrm{g} / \mathrm{ml}\end{array}$ & $\begin{array}{l}\text { Cell viability } \\
\text { after } 24 \mathrm{~h}, \%\end{array}$ \\
\hline 0.000 & $31.26 \pm 2.49$ & $100.00 \pm 3.98$ \\
0.032 & $24.57 \pm 1.48^{\mathrm{a}}$ & $93.67 \pm 6.46$ \\
0.125 & $24.02 \pm 1.93^{\mathrm{a}}$ & $92.70 \pm 5.31$ \\
0.500 & $23.29 \pm 1.08^{\mathrm{a}}$ & $83.41 \pm 5.68^{\mathrm{a}}$ \\
1.000 & $22.79 \pm 3.39^{\mathrm{a}}$ & $60.58 \pm 8.33^{\mathrm{a}}$ \\
2.000 & $24.71 \pm 1.36^{\mathrm{a}}$ & $41.02 \pm 7.26^{\mathrm{a}}$ \\
\hline
\end{tabular}

Effect of different concentrations of camptothecin (CPT) on lipopolysaccharide/interleukin-1 $\beta$-induced nitrite accumulation and cell viability in SW480 cells. The cells were exposed to CPT for $24 \mathrm{~h}$. Results are expressed as the mean \pm standard deviation of 3 observations. ${ }^{a} \mathrm{P}<0.05$ vs. control $(0 \mu \mathrm{g} / \mathrm{ml})$.

Table III. Optical density ratio of RT-PCR in the presence of CPT for $24 \mathrm{~h}$.

\begin{tabular}{lc}
\hline $\begin{array}{l}\text { Concentration } \\
\text { of CPT }, \mu \mathrm{g} / \mathrm{ml}\end{array}$ & Optical density \\
\end{tabular}

\begin{tabular}{ll}
\hline 0.000 & $1.284 \pm 0.008$ \\
0.032 & $1.179 \pm 0.003^{\mathrm{a}}$ \\
0.125 & $1.071 \pm 0.017^{\mathrm{a}}$
\end{tabular}

Reverse transcription-polymerase chain reaction (RT-PCR) analysis of inducible nitric oxide synthase (iNOS) mRNA expression in lipopolysaccharide/interleukin-1 $\beta$ (LPS/IL-1 $\beta$ )-activated SW480 cells with camptothecin (CPT). The cells were treated with LPS plus IL-1 $\beta$ in the co-existence of various concentrations $(0,0.032$ and $0.125 \mu \mathrm{g} / \mathrm{ml}$ ) of CPT for $24 \mathrm{~h}$. Band intensities were quantified by Quantity One software. This experiment was repeated three times with similar results. ${ }^{a} \mathrm{P}<0.05$ vs. control $(0 \mu \mathrm{g} / \mathrm{ml})$.

tion of nitrite production by $2 \mu \mathrm{g} / \mathrm{ml} \mathrm{CPT}$ was not due to cell death. However, significant inhibition of nitrite production by CPT was observed at all concentrations after $24 \mathrm{~h}$ incubation and these effects occurred in a dose-dependent manner. Additionally, there was no significant difference in cell viability among the cells treated with vehicle and 0.032 or $0.125 \mu \mathrm{g} / \mathrm{ml}$ CPT (Table II). This result indicates that lower concentrations of CPT $(0.032$ and $0.125 \mu \mathrm{g} / \mathrm{ml})$ could reduce nitrite production, but not cause cell death.

Effect of CPT on iNOS mRNA expression. To examine whether CPT could inhibit iNOS mRNA expression, RT-PCR was performed, as shown in Fig. 1. The house-keeping gene, GAPDH, was also amplified from each RNA preparation to enable comparisons of the PCR productions in different samples. As shown in Fig. 1 and Table III, iNOS mRNA was significantly suppressed in the presence of CPT, while GAPDH mRNA was not inhibited significantly. This result indicates that CPT inhibits NO production at the transcription level.
Table IV. Optical density ratio of western blotting in the presence of CPT for $24 \mathrm{~h}$.

\begin{tabular}{lc}
\hline $\begin{array}{l}\text { Concentration } \\
\text { of CPT, } \mu \mathrm{g} / \mathrm{ml}\end{array}$ & $\begin{array}{c}\text { Optical density } \\
\text { ratio (iNOS/ } \beta \text {-actin) }\end{array}$ \\
\hline 0.000 & $1.051 \pm 0.024$ \\
0.032 & $0.934 \pm 0.078^{\mathrm{a}}$ \\
0.125 & $0.366 \pm 0.016^{\mathrm{a}}$ \\
\hline
\end{tabular}

Inhibition of inducible nitric oxide synthase (iNOS) protein expression in activated SW480 cells with camptothecin (CPT). The cells were treated with lipopolysaccharide plus interleukin (IL)-1 $\beta$ in the co-existence of various concentrations $(0,0.032$ and $0.125 \mu \mathrm{g} / \mathrm{ml})$ of CPT for $24 \mathrm{~h}$. Band intensities were quantified by Quantity One software. This experiment was repeated three times with similar results. ${ }^{\mathrm{a}} \mathrm{P}<0.05$ vs. control $(0 \mu \mathrm{g} / \mathrm{ml})$.

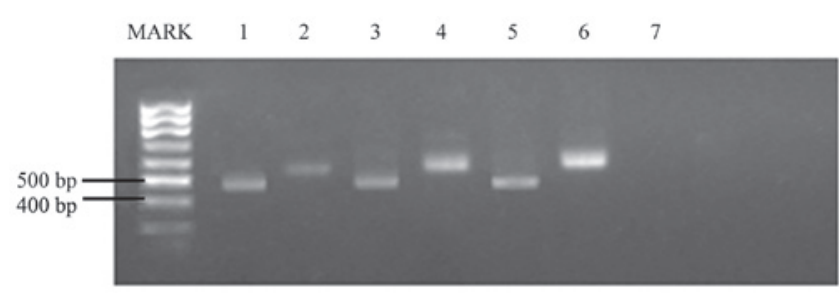

Figure 1. Reverse transcription-polymerase chain reaction analysis of inducible nitric oxide synthase (iNOS) mRNA expression in lipopolysaccharide/interleukin-1 $\beta$ (LPS/IL-1 $\beta$ )-activated SW480 cells with by camptothecin $(\mathrm{CPT})$. The cells were treated with LPS plus IL-1 $\beta$ in the co-existence of various concentrations $(0.125,0.032$ and $0 \mu \mathrm{g} / \mathrm{ml})$ of CPT for $24 \mathrm{~h}$. Lanes 1 , 3 and 5 show GAPDH expression with the three concentrations of CPT, respectively. Lanes 4 and 6 show iNOS mRNA expression in cells with CPT concentrations of 0.032 and $0 \mu \mathrm{g} / \mathrm{ml}$, and lane 2 shows iNOS mRNA expression in cells with CPT at concentrations of $0.125 \mu \mathrm{g} / \mathrm{ml}$.

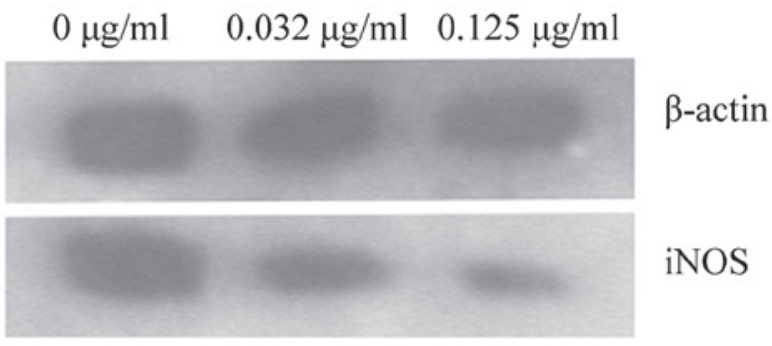

Figure 2. Inhibition of inducible nitric oxide synthase (iNOS) protein expression in activated SW480 cells with camptothecin (CPT). The cells were treated with lipopolysaccharide plus interleukin-1 $\beta$ in the co-existence of various concentrations $(0,0.032$ and $0.125 \mu \mathrm{g} / \mathrm{ml})$ of CPT for $24 \mathrm{~h}$.

Effect of CPT on iNOS protein expression. To determine whether the NO inhibitory effect of CPT was due to the inhibition of iNOS protein expression, western blot analysis was performed. The inhibition of 142-kDa iNOS protein expression by CPT is shown in Fig. 2. Marked suppression was observed at the two concentrations. As $\beta$-actin protein was not markedly affected, cell viability was not changed (Fig. 2; Table IV). This result indicates that the inhibition of iNOS protein expression is one of the mechanisms of NO inhibition. 


\section{Discussion}

A number of the anticancer mechanisms of CPT have previously been revealed. Studies have shown that the antitumor activity is associated with the inhibition of topoisomerase I (3), and that CPT may exhibit an inhibitory effect on the development of the vasculature (8) and the apoptosis of cancer cells (9). In the present study, it was shown that CPT can effect the nitrite production of SW480 cells in a process that is independent of cytotoxicity. In order to further understand the mechanisms of action for NO inhibition, the levels of iNOS mRNA and protein expression were determined. RT-PCR and western blotting data showed that interference with iNOS mRNA and protein expression may be a factor contributing to the inhibitory effect of CPT on iNOS enzyme activity and NO production in SW480 cells. This result has not been reported in previous studies.

iNOS is overexpressed in colon tumors, and NO is important during the progression of colon carcinoma. The associated mechanisms involve inhibiting apoptosis, improving angiogenesis and enhancing the expression of proto-oncogenes. This suggests that iNOS can be the target of anticancer agents. As an effective anticancer agent, CPT can inhibit colon tumors. From the present experiments, it can be concluded that the inhibition of nitrite production should be a novel mechanism underlying the effect of CPT against colon cancer.

\section{References}

1. Wall ME,Wani MC, Cook CE, Palmer KH, McPhail AT and Sim GA. Plant antitumor agents. I. The isolation and structure of camptothecin, a novel alkaloidal leukemia and tumor inhibitor from Camptotheca accuminata. J Am Chem Soc 88: 3888-3890, 1966.

2. Garcia-Carbonero R and Supko JG: Current perspectives on the clinical experience, pharmacology and continued development of the camptothecins. Clin Cancer Res 8: 641-661, 2002.

3. Hsiang YH, Wu HY and Liu LF: Proliferation-dependent regulation of DNA topoisomerase II in cultured human cells. Cancer Res 48: 3230-3235, 1988.

4. Abounader R, Reznik T, Colantuoni C, Martinez-Murillo F, Rosen EM and Laterra J: Regulation of c-Met-dependent gene expression by PTEN. Oncogene 23: 9173-9182, 2004.

5. Hamano Y and Kalluri R: Tumstatin, the NC1 domain of alpha3 chain of type IV collagen, is an endogenous inhibitor of pathological angiogenesis and suppresses tumor growth. Biochem Biophys Res Commun 333: 292-298, 2005.
6. Fox SB, Gatter KC, Bicknell R, Going JJ, Stanton P, Cooke TG and Harris AL: Relationship of endothelial cell proliferation to tumor vascularity in human breast cancer. Cancer Res 53: 4161-4163, 1993.

7. D'Amato RJ, Loughnan MS, Flynn E and Folkman J: Thalidomide is an inhibitor of angiogenesis. Proc Natl Acad Sci U S A 91: 4082-4085, 1994.

8. Bezerra Y, Fuselier JA, Peyman GA, Oner H, Drouant G and Coy DH: Study of inhibitory effects of an antiangiogenic somatostatin-camptothecin conjugate on laser-induced choroidal neovasculrization in rats. Retina 25: 345-354, 2005.

9. Panrazis P, Han Z, Balan K, Wang Y and Wyche JH: Camptothecin and 9-nitrocamptothecin (9NC) as anti-cancer anti-HIV and cell-differentiation agents. Development of resistance, enhancement of 9NC-induced activities and combination treatments in cell and animal models. Anticancer Res 23: 3623-3638, 2003.

10. Jenkins DC, Charlies IG, Thomsen LL, Moss DW, Holmes LS, Baylis SA, Rhodes P, Westmore K, Emson PC and Moncada S: Roles of nitric oxide in tumor growth. Proc Natl Acad Sci USA 92: 4392-4396, 1995.

11. Klotz T, Bloch W, Jacobs G, Niggemann S, Engelmann U and Addicks K: Immunolocalization of inducible and constitutive nitric oxide synthases in human bladder cancer. Urology 54: 416-419, 1999.

12. Zhang GL, Wang YH, Teng HL and Lin ZB: Effects of aminoguanidine on nitric oxide production induced by inflammatory cytokines and endotoxin in cultured rat hepatocytes. World $\mathbf{J}$ Gastroenterol 7: 331-334, 2001.

13. Jenkins DC, Charles IG, Baylis SA, Lelchuk R, Radomski MW and Moncada S: Human colon cancer cell lines show a diverse pattern of nitric oxide synthase gene expression and nitric oxide generation. Br J Cancer. 70: 847-849, 1994.

14. Sherman PA, Lanbach VE, Reep BR and Wood ER: Purification and cDNA sequence of an inducible nitric oxide synthase from a human tumor cell line. Biochemistry 32: 11600-11605, 1993.

15. Franchi A, Gallo O, Paglierani M, Sardi I, Magnelli L, Masini E and Santucci M: Inducible nitric oxide synthase expression in laryngeal neoplasia: Correlation with angiogenesis. Head Neck 24: 16-23, 2002.

16. Son HJ, Kim YH, Park DI, Kim JJ, Rhee PL, Paik SW, Choi KW, Song SY and Rhee JC: Interaction between cyclooxygenase-2 and inducible nitric oxide synthase in gastric cancer. J Clin Gastroenterol 33: 383-388, 2001.

17. Ray GN, Shahid M and Hasain SA: Effect of nitric oxide and malondialdehyde on sister-chromatid exchanges in breast cancer. Br J Biomed Sci 58: 169-176, 2001.

18. Chiou WF, Chou CJ and Chen CF: Camptothecin suppresses nitric oxide biosynthesis in RAW 264.7 macrophages. Life Sci 69: 625-635, 2001.

19. Green LC, Wagner DA, Glogowski J, Skipper PL, Wishnok JS and Tannenbaum SR: Analysis of nitrate, nitrite and $15 \mathrm{~N}$ nitrate in biological fluids. Anal Biochem 126: 131-138, 1982. 